\title{
Comparison of Teachers and Pre-Service Teachers with Respect to Personality Traits and Career Adaptability
}

\section{Ali Eryılmaz}

Assoc. Prof., Eskişehir Osmangazi University, Faculty of Education, Turkey, erali76@hotmail.com

\author{
Ahmet Kara \\ Eskişehir Osmangazi University, Faculty of Education, Turkey, \\ ahmetkara9126@gmail.com
} personality traits and career adaptability. The relationships between personality traits and career adaptability are also investigated. A total of 176 pre-service teachers took part in the study, including 90 men and 76 women, and a total of 204 teachers took part in the study, including 98 men and 106 women. The data collected included items from the Big Five Inventory and the Scale of Career Adaptability. The relationship between variables was examined by using independent t-tests for gender differences and multiple regression analysis techniques. According to the results, the level of career adaptability is higher in teachers than in pre-service teachers. Additionally, career exploration and plans were related to certain personality traits. The results of the present study might be used in career counselling, and also teacher profession development.

Key Words: career adaptability, pre-service teachers, teachers, personality traits, personality

\section{INTRODUCTION}

Many factors impact the learning and teaching process in the educational environment. One of these factors is the teachers (Eryllmaz, 2014). Teachers possess many qualities that are effective for both getting satisfaction from their teaching and being successful in their professions. Personality characteristics and career adaptability are examples of these qualities (Nauta \& Derckx, 2007. The relationships between these two variables in terms of teachers and pre-service teachers who work in the same area in Turkish culture have been examined comparatively with the purpose of contributing to the literature.

Work lives and the time spent in working life constitute significant parts of individuals' lives. Many factors enable the adaptation of individuals to work life. One of these factors is career adaptability. Career adaptability is a multidimensional and psycho- 
social structure (Savickas, 2012). Career adaptability, the capacity of individuals to cope with future changes, and the level of coping with new job responsibilities are defined as the abilities to cope with unpredictable career changes (Rottinghaus, Day \& Borgen, 2005). To Creed, Fallon and Hood (2009) career adaptability is an individual regulation with a function of exploring themselves and their environment, and also includes career planning and decision making. Career adaptability has been examined by various researchers (Stumpf, Colarelli \& Hartman, 1983) in several dimensions: career exploration and career planning, concern, control, curiosity and confidence (Savickas \& Porfeli, 2012). Both individual and environmental factors are effective in individuals' career development and career adaptability (Krumboltz, 1996). Personality characteristics should be evaluated in the context of individual factors (Nauta \& Derckx, 2007).

Personality characteristics are features that people carry everywhere (McRea \& Costa, 2003). The personality characteristics of teachers are reflected in learning and teaching processes (De Raad \& Schouwenburg, 1996). Studies have found that teachers' personality characteristics have an effect on being an effective teacher (Erdle, Murray, \& Rushton, 1985; Srivastava \& Bhargava, 1984), on students' academic achievement (Patrick, 2011), on the subjective well-being of students, the use of effective teaching methods (Eryllmaz, 2014) and on the relationship between teachers and students (Yoon, 2002). Teachers' personality characteristics may also be related to the development of their careers because the career interests and preferences of individuals are influenced by personality characteristics (Holland, 1997; Nauta \& Derckx, 2007).

In the literature, the relationship between personality characteristics and career adaptability has been examined using the Five Factor Model (Costa \& McCrae, 1992). Studies related to personality characteristics and adaptability to careers has focused more on career exploration dimensions. In studies on career exploration, extraversion, neuroticism, openness to experience, and conscientiousness were found to be associated with personality characteristics (Nauta \& Derckx, 2007; Reed et al., 2004; Solberg \& Srther, 1994). In this regard, very few studies have examined the relationship between personality characteristics and career planning. However, planning is also a dimension of career adaptability (Creed, Fallon \& Hood, 2009).

Studies on students (Kavas, Duffy \& Douglass, 2015; Cheung, Fan \& Yao, 2012; Nauta \& Derckx, 2007) and workers (Zacher, 2014) have examined the relationship between career adaptability and personality characteristics. There are very few comparative studies on both teachers and pre-service teachers. Teachers are in the adulthood period and university students are in the emerging adulthood period (Arnet, 2004, 2005). However, university students are trying to explore their identity in work, love and worldview, whereas teachers seem to have completed this process (Arnet, 2001). If individuals are in different periods and strive to do the same job, the relationship between their career adaptability and personality characteristics may vary. Additionally, career adaptability leads to increases in individuals' commitment to their jobs (Rossier et al., 2012), less work stress (Johnston et al., 2013), rising individual work satisfaction (Fiori, Bollmann \& Rossier, 2015), more positive career achievements (Zikic \& Klehe, 
2006) and academic satisfaction (Duffy, Douglass \& Autin, 2015). It is important to work on an issue that helps the emergence of positive features. Moreover, career exploration is a life-long process (Blustein, 1992; Super, 1980). In the literature, in both cross-sectional and longitudinal studies, receiving university education as a teacher explains the relationship between personality characteristics and adaptability. As a result, the purpose of this study is to examine the relationship between the personality characteristics of teachers and pre-service teachers and their career adaptability.

\section{METHOD}

\section{Research Design}

The aim of the present study is to compare teachers and pre-service teachers in terms of personality characteristics and career adaptability. There have been four sub-goals of the present study:

- To compare teachers' and pre-service teachers' perceptions on career adaptability and personality traits.

- To examine the relationships between career adaptability and personality traits of pre-service teachers.

- To examine the relationships between career adaptability and personality traits of teachers.

The study was carried out in a cross-sectional model. The relationship between variables was examined using independent t-test and multiple regression analysis techniques for independent groups. In the study, a maximum variety sampling method was selected (Freankel \& Wallen, 2006). As inclusion criteria, for pre-service teachers, they had to be final year students and studying primary school science and math. Conversely, for working teachers, the criteria were as follows: primary class teachers and science and mathematics teachers with at least 10 years of teaching. The data were collected by the researchers as a group.

\section{Study Groups}

In this study, two different groups of individuals participated in the study, teachers and pre-service teachers. Pre-service teachers were selected from among the Faculty of Education students studying at a public university in Eskisehir, Turkey. In this study, the purposive sampling method which is characterized to select the most suitable observation unit from the universe has been used. A total of 176 pre-service teachers took part in the study, including 90 men and 76 women. There were $56(31.82 \%)$ primary class teacher candidates, $59(33.52 \%)$ science pre-service teachers and $61(35.66 \%)$ math pre-service teachers receiving education. The age range of the preservice teachers was $20-24$. Their mean age was 21.27 , and the standard deviation was 1.19 .

A total of 204 teachers took part in the study, including 98 men and 106 women. There were $72(35.29 \%)$ primary class teachers, $64(31.57 \%)$ science teachers and $68(33.33$ 
$\%)$ math teachers. The age range of teachers was 36-60. Their mean age was 43.60, and the standard deviation was 6.78 .

\section{Instrument}

The Big Five Inventory: The scale was developed by Benet-Martine and John (1998). The Turkish adaptation of the scale was made by Sümer, Lajunen and Özkan (2005). The five-point Likert-type scale consists of 44 items. The scale consists of the following five factors: openness, conscientiousness, extraversion, agreeableness and neuroticism. In the study of scale adaptation, the Cronbach's alpha internal consistency of neuroticism, extraversion, openness, agreeableness, and conscientiousness were 0.79 , $0.78,0.76,0.70$ and 0.78 , respectively.

Career Adaptability Scale: This scale was developed by Eryılmaz and Kara (2016). The five Point Likert-type scale consists of 10 items and two dimensions, career exploration and career planning. Career planning has included goal setting, striving career goals and make a career plan. Career exploration has included exploration of self and environment in terms of career (Eryılmaz \& Kara, 2016; Stumpf, Colarelli \& Hartman, 1983). To examine the psychometric properties of the scale, internal consistency, test-retest method, item analysis, exploratory factor analysis, criterion validity and construct validity studies were conducted by Eryılmaz and Kara (2016). The career exploration scale's internal consistency coefficient is 0.84 , the career plan's internal consistency coefficient is 0.71 and the entire scale's internal consistency coefficient is 0.85 . The reliability coefficients of career exploration from the test-retest method were 0.82 , and the career plan's reliability coefficients were 0.87 . According to the results of the exploratory factor analysis, the two dimensions explained $55.87 \%$ of the variance. The scale factor loads ranged between 0.57 and 0.80 . The correlation analysis was conducted on the career Future Scale. There was a highly positive correlation of 0.64 between the Career Adaptability Scale and Career Future Scale. Confirmatory factor analysis was conducted on the construct validity. According to the results of the analysis of the twodimensional scale, the value of RMSEA was 0.071 , the degree of freedom was 34 , and the chi square value was 70.75 . Dividing the chi square by the degree of freedom $(70.75$ / $34=2.08$ ) yielded a value of 2.08 . The goodness of adaptability values from the confirmatory factor analysis of the Career Adaptability Scale were as follows: NFI, 0.95; NNFI, 0.97; IFI, 0.98; CFI, 0.98; GFI, 0.94 and AGFI, 0.90. According to the results of the confirmatory factor analysis, it was concluded that the scale consisted of two dimensional structures and the scale yielded good adaptability values. In conclusion, the scale was reliable and valid. 


\section{FINDINGS}

\section{Descriptive Statistics}

Table1

Descriptive statistics

\begin{tabular}{lllll}
\hline Variables & Group & $N$ & $M$ & $S D$ \\
\hline \multirow{2}{*}{ Exploration } & Teacher & 204 & 25.51 & 3.60 \\
\cline { 2 - 5 } Plan & Pre-Service Teacher & 176 & 24.21 & 4.62 \\
\hline \multirow{2}{*}{ Career Adaptability } & Teacher & 204 & 15.68 & 2.89 \\
\cline { 2 - 5 } & Pre-Service Teacher & 176 & 14.88 & 2.95 \\
\hline \multirow{2}{*}{ Extraversion } & Teacher & 204 & 41.20 & 5.73 \\
\cline { 2 - 5 } & Pre-Service Teacher & 176 & 39.09 & 6.89 \\
\hline \multirow{2}{*}{ Agreeableness } & Teacher & 204 & 29.13 & 5.18 \\
\hline \multirow{2}{*}{ Conscientiousness } & Pre-Service Teacher & 176 & 28.09 & 5.96 \\
\hline \multirow{2}{*}{ Neuroticism } & Teacher & 204 & 36.98 & 6.28 \\
\cline { 2 - 5 } & Pre-Service Teacher & 176 & 34.53 & 4.95 \\
\hline \multirow{2}{*}{ Openness } & Teacher & 204 & 35.19 & 6.80 \\
\cline { 2 - 5 } & Pre-Service Teacher & 176 & 32.76 & 5.21 \\
\hline & Teacher & 204 & 21.47 & 5.98 \\
\cline { 2 - 5 } & Pre-Service Teacher & 176 & 23.17 & 5.79 \\
\cline { 2 - 5 } & Teacher & 204 & 38.37 & 5.78 \\
\cline { 2 - 5 } & Pre-Service Teacher & 176 & 36.49 & 5.41 \\
\hline
\end{tabular}

Findings of the comparison of teachers and pre-service teachers with respect to career adaptability

There were significant differences in terms of the teachers' and the pre-service teachers' career adaptability and personality characteristics. There were significant differences $\mathrm{t}(377)=3.24, \mathrm{p}=0.00$ between teachers $(\mathrm{M}=41.20 ; \mathrm{SD}=5.73)$ and pre-service teachers $(M=39.09 ; \mathrm{SD}=6.89)$ in terms of the total points of the career adaptability scale. Career adaptability was higher in the teachers than in the pre-service teachers.

There were significant differences $\mathrm{t}(377)=3.07, \mathrm{p}=0.00$ between teachers $(\mathrm{M}=25.51$; $\mathrm{SD}=3.60)$ and pre-service teachers $(\mathrm{M}=24.21 ; \mathrm{SD}=4.62)$ in terms of career exploration. Career exploration is higher in teachers than in pre-service teachers. There were significant differences $\mathrm{t}(377)=2.68, \mathrm{p}=0.00$ between teachers $(\mathrm{M}=15.68 ; \mathrm{SD}=2.89)$ and pre-service teachers $(\mathrm{M}=14.88 ; \mathrm{SD}=2.95)$ in terms of career planning. Career planning is higher in teachers than pre-service teachers.

Findings of the comparison of teachers and pre-service teachers with respect to personality traits

There was no significant difference $(t(377)=1.80, \mathrm{p}=0.070)$ between teachers and preservice teachers in the extroversion personality feature. Significant differences $\mathrm{t}(377)=$ $4.15, \mathrm{p}=0.00$ between teachers $(\mathrm{M}=36.98 ; \mathrm{SD}=6.28)$ and pre-service teachers $(\mathrm{M}=34.53$; $\mathrm{SD}=4.95)$ were found in terms of agreeableness. There were significant differences $\mathrm{t}(377)=3.85, \mathrm{p}=0.00$ between teachers $(\mathrm{M}=35.19 ; \mathrm{SD}=6.80)$ and pre- 
service teachers $(M=32.76 ; S D=5.21)$ in terms of conscientiousness. There were significant differences $\mathrm{t}(377)=-2.80, \mathrm{p}=0.00$ between teachers $(\mathrm{M}=21.47 ; \mathrm{SD}=5.98)$ and pre-service teachers $(\mathrm{M}=23.17 ; \mathrm{SD}=5.79)$ in terms of neuroticism. There were significant differences $\mathrm{t}(377)=3.26, \mathrm{p}=0.00$ between teachers $(\mathrm{M}=38.37 ; \mathrm{SD}=5.78)$ and pre-service teachers $(\mathrm{M}=36.49 ; \mathrm{SD}=5.41)$ in the dimensions of openness. In conclusion, openness, conscientiousness, agreeableness, and neuroticism personality features are higher in teachers than pre-service teachers. Furthermore, teachers have less neuroticism than pre-service teachers.

\section{Findings of the relationships between personality traits and career adaptability of teachers}

The relationship between teachers' personality characteristics with the career adaptability scale dimensions of career planning and dimensions of career exploration were analyzed using the multiple-regression technique.

The extroversion personality trait of teachers was significantly related to career adaptability, $\beta=0.23, \mathrm{t}(198)=2.88, \mathrm{p}<0.01$. The agreeableness of teachers was significantly related to career adaptability, $\beta=0.17, \mathrm{t}(198)=2.35, \mathrm{p}<0.05$. Similarly, the conscientiousness of teachers was significantly related to career adaptability, $\beta=$ $0.15, \mathrm{t}(198)=2.23, \mathrm{p}<0.05$. Conversely, the neuroticism of teachers was not significantly related to career adaptability, $\beta=-0.09, \mathrm{t}(198)=-1.24, \mathrm{p}>0.05$. Similarly, the openness of teachers was not significantly related to career adaptability, $\beta=-0.00, t$ $(198)=-0.06, \mathrm{p}>0.05$.

The extroversion of teachers was significantly related to the sub-dimension of career exploration, $\beta=0.24, \mathrm{t}(198)=2.97, \mathrm{p}<0.01$. The agreeableness of teachers was significantly related to the sub-dimension of career exploration, $\beta=0.16$, $\mathrm{t}(198)=2.22$, $\mathrm{p}<0.05$. Similarly, the conscientiousness of teachers significantly described the subdimension of career exploration, $\beta=0.18, \mathrm{t}(198)=2.53, \mathrm{p}<0.05$. Conversely, the neuroticism of teachers was not significantly related to the sub-dimension of career exploration, $\beta=-0.07, \mathrm{t}(198)=-0.99, \mathrm{p}>0.05$. Additionally, the openness of teachers was not significantly related to the sub-dimension of career exploration, $\beta=-0.02, \mathrm{t}$ $(198)=-0.26, \mathrm{p}>0.05$.

The extroversion of teachers was not significantly related to the sub-dimension of career planning, $\beta=0.16, \mathrm{t}(198)=1.90, \mathrm{p}>0.05$. The agreeableness of teachers was not significantly related to the sub-dimension of career planning, $\beta=0.13, \mathrm{t}(198)=1.80, \mathrm{p}>0.05$. Similarly, the conscientiousness of teachers was not significantly related to the sub-dimension of career planning, $\beta=0.09, \mathrm{t}(198)=1.19, \mathrm{p}>0.05$. In the same way, the neuroticism of teachers was not significantly related to the sub-dimension of career planning, $\beta=-0.09$, t $(198)=-1.16, p>0.05$. Similarly, the openness of teachers was not significantly related to the sub-dimension of career planning, $\beta=0.02, \mathrm{t}(198)=0.20, \mathrm{p}>0.05$. 
Table-2

The relationships between personality traits and the career adaptability of teachers

\begin{tabular}{lllllll}
\hline & $B$ & $S E B$ & $\beta$ & $R^{2}$ & $\Delta R^{2}$ & $F$ \\
\hline Total Point of Career Adaptability & & & & .20 & $.20^{* *}$ & 10.06 \\
Extraversion & .25 & .09 & $.23^{* *}$ & & & \\
Agreeableness & .15 & .07 & $.17^{*}$ & & & \\
Conscientiousness & .13 & .06 & $.15^{*}$ & & & \\
Neuroticism & -.09 & .07 & -.09 & & & \\
Openness & -.01 & .08 & -.00 & & & \\
\hline Exploration & & & & .20 & $.20^{* *}$ & 9.75 \\
Extraversion & .16 & .06 & $.24^{* *}$ & & & \\
Agreeableness & .09 & .04 & $.16^{*}$ & & & \\
Conscientiousness & .09 & .04 & $.18^{*}$ & & & \\
Neuroticism & -.05 & .05 & -.07 & & & \\
Openness & -.01 & .05 & -.02 & & & \\
Planning & & & & .12 & $.12^{* *}$ & 5.21 \\
Extraversion & .09 & .05 & .16 & & & \\
Agreeableness & .06 & .03 & .13 & & & \\
Conscientiousness & .04 & .03 & .09 & & & \\
Neuroticism & -.04 & .04 & -.09 & & & \\
Openness & .01 & .04 & .02 & & & \\
\hline
\end{tabular}

Findings of the relationships between personality traits and career adaptability of pre-service teacher

Table 3

The relationships between the personality traits and career adaptability of pre- teachers service

\begin{tabular}{lcccccc}
\hline \multicolumn{1}{c}{$B$} & $B$ & $S E B$ & $\beta$ & $R^{2}$ & $\Delta R^{2}$ & $F$ \\
\hline Total Point of & & & & .16 & $.16^{* *}$ & 6.31 \\
Career Adaptability & & & & & & \\
Extraversion & .30 & .08 & $.27^{* *}$ & & & \\
Agreeableness & .23 & .10 & $.17^{*}$ & & & \\
Conscientiousness & .22 & .09 & $.17^{*}$ & & & \\
Neuroticism & .23 & .08 & $-.20^{*}$ & & & 5.26 \\
Openness & .00 & .09 & .00 & & $.13^{* *}$ & \\
\hline Exploration & & & & .13 & & \\
Extraversion & .15 & .06 & $.20^{*}$ & & & \\
Agreeableness & .20 & .07 & $.22^{* *}$ & & & \\
Conscientiousness & .10 & .06 & .12 & & & \\
Neuroticism & .17 & .06 & $-.23^{* *}$ & & & \\
Openness & .00 & .06 & .00 & & .11 \\
\hline Planning & & & & $.15^{* *}$ & \\
Extraversion & .15 & .03 & $.30^{* *}$ & & & \\
Agreeableness & .03 & .04 & .05 & & & \\
Conscientiousness & .11 & .04 & $.21^{*}$ & & & \\
Neuroticism & .05 & .03 & -.10 & & & \\
Openness & -.00 & .04 & -.00 & & & \\
*p<0.05; **p<0.01 & & & & & & \\
\end{tabular}


The relationship between the teachers' personality characteristics with the total points of career adaptability scale dimensions of career planning and dimensions of career exploration were analyzed using the multi-regression technique. The analysis results are listed in Table-3

The extroversion of pre-service teachers was significantly related to career adaptability, $\beta=0.27, \mathrm{t}(170)=3.46, \mathrm{p}<0.01$. The agreeableness of teachers candidates was significantly related to career adaptability, $\beta=0.17, \mathrm{t}(170)=2.18, \mathrm{p}<0.05$. Similarly, the conscientiousness of pre-service teachers was significantly related to career adaptability, $\beta=0.17, \mathrm{t}(170)=2.27, \mathrm{p}<0.05$. In the same way, the neuroticism of preservice teachers was significantly related to career adaptability, $\beta=-0.20, \mathrm{t}(170)=2.58$, $\mathrm{p}<0.05$. Conversely, the openness of pre-service teachers was not significantly related to career adaptability, $\beta=0.00, \mathrm{t}(170)=0.00, \mathrm{p}>0.05$.

The extroversion of teacher candidates was significantly related to the sub-dimension of career exploration, $\beta=0.20, \mathrm{t}(170)=2.61, \mathrm{p}<0.05$. The agreeableness of pre-service teachers was significantly related to the sub-dimension of career exploration, $\beta=0.22, \mathrm{t}$ $(170)=2.80, p<0.01$. Conversely, the conscientiousness of pre-service teachers was not significantly related to the sub-dimension of career exploration, $\beta=0.12, \mathrm{t}(170)=$ $1.60, \mathrm{p}>0.05$. The neuroticism of pre-service teachers was significantly related to the sub-dimension of career exploration, $\beta=-0.23, \mathrm{t}(170)=2.93, \mathrm{p}<0.01$. Conversely, the openness of teacher candidates was not significantly related to the sub-dimension of career exploration, $\beta=0.00, \mathrm{t}(170)=0.01, \mathrm{p}>0.05$.

The extroversion of pre-service teachers was significantly related to the sub-dimension of career planning, $\beta=0.30, \mathrm{t}(170)=3.93, \mathrm{p}<0.01$. Conversely, the agreeableness of pre-service teachers was not significantly to the sub-dimension of career planning, $\beta=$ $0.05, \mathrm{t}(170)=0.66, \mathrm{p}>0.05$. The conscientiousness of pre-service teachers was significantly related to the sub-dimension of career planning, $\beta=0.21$, t $(170)=2.75$, $p$ $<0.05$. Conversely, the neuroticism of teacher candidates was not significantly related to the sub-dimension of career planning, $\beta=-0.10, \mathrm{t}(170)=1.36, \mathrm{p}>0.05$. Similarly, the openness of pre-service teachers was not significantly related to the sub-dimension of career planning, $\beta=-0.00, \mathrm{t}(170)=-0.02, \mathrm{p}>0.05$.

Table 4

Summary of results

\begin{tabular}{lcc}
\hline & Teachers & Pre-service teachers \\
\hline Total Point of Career Adaptability & & \\
Extraversion & ++ & ++ \\
Agreeableness & + & + \\
Conscientiousness & + & + \\
Neuroticism & - & + \\
Openness & - & - \\
\hline Exploration & & \\
Extraversion & ++ & + \\
Agreeableness & + & ++ \\
Conscientiousness & + & - \\
Neuroticism & - & ++ \\
Openness & - & - \\
\hline
\end{tabular}




\begin{tabular}{llc}
\hline Planning & & ++ \\
Extraversion & - & - \\
Agreeableness & - & + \\
Conscientiousness & - & - \\
Neuroticism & - & - \\
Openness & - & $-:$ Not important; $* \mathrm{p}<0.05 ; *$ p $<0.01$ \\
\hline$++:$ Very important, & + : Important, &
\end{tabular}

\section{DISCUSSION}

In this study, the relationship between teachers' and pre-service teachers' career adaptability and personality characteristics were comparatively analyzed. The personality characteristics and career adaptability of teachers and pre-service teachers were found to have similar and different aspects. The findings show parallels with international research results. Generally, when the results were evaluated, the differences between teachers and pre-service teachers in terms of personality characteristics can be explained by teachers and pre-service teachers taking part in different developmental stages. It was observed that teachers in adulthood scored higher than pre-service teachers in terms of personality characteristics other than extraversion. These research findings show parallels with the study results performed by Eryılmaz \& Ercan (2011). When the results were evaluated in terms of personality development, the studies show that extraversion decreases and conscientiousness increases from adolescence to adulthood. Similarly, in parallel with the increase in the emotion regulation skills, neuroticism also decreases over time (McCrea \& Costa, 2003). In addition, the most important property for the transition to adulthood is conscientiousness (Arnet, 2003). As a result, the adulthood period may mean more maturity for individuals involved in the previous period. This maturity can lead to the emergence of differences in personality characteristics. Similarly, the differences between teachers and pre-service teachers in terms of career adaptability and both professional and overall development of individuals who involved in the two groups can be explained by the two groups taking part in different periods. Pre-service teachers are involved in the young adulthood period. Identity crises, instability, self-focus, and many opportunities are key features of the emerging adulthood period (Arnet, 2004, 2005). One of the dimensions of identity exploration is a working life. As a result, because individuals in this period have yet to experience the identity exploration process, career adaptability levels compared with individuals in the next period could be significantly lower. Emerging adults are in the research stage, and teachers are in the settlement stage in terms of professional development periods. There are three steps in the settlement stage. One of them is the strengthening step (Super, 1980; Super \& Bohn, 1970). The teachers who were involved in the study were completely part of this step. Taking place in different developmental stages in terms of career adaptability and sub-dimensions may lead to the emergence of differences between the two groups.

In the international studies, it was found that personality exploration was associated with extraversion, openness and conscientiousness (Kavas, Duffy \& Douglass, 2015; Cheung, Fan \& Yao, 2012; Nauta \& Derckx, 2007; Zacher, 2014). In general, the findings of this study coincide with the literature, and it has been observed that agreeableness is 
important for both teachers and pre-service teachers. The reason why the personality feature of agreeableness is important can be explained with cultural factors. Studies in areas such as cultural psychology show that societies are assessed in two dimensions, individualistic and collectivistic cultures (Triandis, 1994, 1996). Studies in Turkey show that in Turkish society, both collectivist and individualist cultures are observed together and even transform to related selves (Kağıtçıbaşı, 1996; Kağıtçıbaşı \& Ataca, 2005). Collective structures or related selves are required to live together, to see others' views and suggestions and to find social cohesion. These features appear in many areas such as interpersonal relationships, work life and job hiring. Agreeableness is closely associated with these properties. Therefore, the relationships between career adaptability and agreeableness emerged in this study.

In addition to the above findings, in the international studies, a significant relationship between the personality features of openness and career adaptability has been found (Kavas, Duffy \& Douglass, 2015; Cheung, Fan \& Yao, 2012; Nauta \& Derckx, 2007; Zacher, 2014). In this study, no relationship between the personality features of openness and career adaptability was found for both teachers and pre-service teachers. The main reason for this result may be the teacher employment policies in Turkey. In Turkey, the majority of teachers work in public schools (91\%), and very few of them work in private schools $(9 \%)$. The career options for teachers working in the public sector in the Turkish education system are very narrow. In order for both teacher and pre-service teachers to consider other career options, they must activate the personality feature of openness.

In this study, although conscientiousness and extraversion personality features are related to each other in terms of career adaptability's planning dimension for pre-service teachers, there is no relation to personality features for teachers. Studies conducted in the literature on pre-service teachers explain why these personality characteristics are effective. For example, extroverted individuals are more social, which makes career exploration easier. Conscientious individuals exhibit goal-oriented behaviour. Therefore, it is important to successfully overcome the duties associated with large responsibilities of career adaptability (Reed et al., 2004; Nauta \& Derckx, 2007). The reason for the absence of the relationship between teachers' career planning with personality characteristics may be the different era of pre-service teachers in terms of both general and professional development and the narrowness of career options for teachers in Turkey.

\section{CONCLUSION}

Studies examining the relationship between career adaptability and personality characteristics have mostly examined relationships between career exploration and personality characteristics (Nauta \& Derckx, 2007; Reed et al., 2004; Solberg \& Srther, 1994). In this study, the relationship between career exploration and the dimensions of planning with personality characteristics were examined. In addition, a cross-sectional comparison was made with individuals at two different developmental stages. At this point, it can be said that this study has provided important contributions to the literature. However, this study is cross-sectional and not longitudinal. In the future, longitudinal studies should also be conducted to contribute to literature on the same subject. 


\section{REFERENCES}

Arnett, J. J. (2001). Conceptions of the transition to adulthood: Perspectives from adolescence to midlife. Journal of Adult Development 8: 133-143.

Arnett, J. J. (2003). Conceptions of the transition to adulthood among emerging adults in American ethnic groups. New Directions in Child and Adolescent Development 100: 63-75.

Arnett, J. J. (2004). Emerging adulthood: The winding road from the late teens through the twenties. New York: Oxford University Press.

Arnett, J. J. (2005). The developmental context of substance use in emerging adulthood. Journal of Drug Issues 35: 235-253.

Benet-Martínez, V., \& John, O. P. (1998). Los Cinco Grandes across cultures and ethnicgroups: Multitrait method analyses of the Big Five in Spanish and English. Journal of Personality and Social Psychology 75: 729-750.

Blustein, D. L. (1992). Applying current theory and research in career exploration to practice. Career Development Quarterly 41: 174-184.

Cheung, F. M., Fan, W. Q., \& Yao, D. J. (2012). Chinese personality and vocational behavior. In X. Huang \& M. H. Bond (Eds.), The handbook of Chinese organizational behavior: Integrating theory, research, and practice (pp. 359-379). Cheltenham, England: Edward Elgar.

Costa, P. T., McCrae, R. R. (1992). Four ways five factors are basic. Personality and Individual Differences 13 (6): 653-665.

Creed, P. A., Fallon, T., \& Hood, M. (2009). The relationship between career adaptability, person and situation variables, and career concerns in young adults. Journal of Vocational Behavior 74: 219-229.

De Raad, B., \& Schouwenburg, H. C. (1996). Editorial: personality, learning, and education. European Journal Of Personality 10: 303-336.

Duffy, R. D., Douglass, R. P., \& Autin, K. L. (2015). Career adaptability and academic satisfaction: Examining work volition and self-efficacy as mediators. Journal of Vocational Behavior 90: 46-54.

Erdle, S., Murray, H. G., \& Rushton, P., (1985). Personality, classroom behavior and student rating of college teaching effectiveness: a path analysis. Journal of Education Psychology 77: 394-406.

Eryllmaz, A. (2014). Perceived personality traits and types of teachers and their relationship to the subjective well-being and academic achievements of adolescents. Educational Sciences: Theory \& Practice 14 (6): 2049-2062. 
Eryllmaz A., \& Ercan L. (2011). Investigating of the subjective wellbeing based on gender, age and personality. Turkish Psychological Counseling and Guidance 39: 139151.

Eryılmaz, A., \& Kara, A. (2016). Investigation of psychometric properties of career adaptability scale. The Online Journal of Counseling and Education 5 (1): 29-39.

Fiori, M., Bollmann, G., Rossier, J. (2015). Exploring the path through which career adaptability increasese job satisfaction and lowers job stress: The role of affect. Journal of Vocational Behavior 91: 113-121.

Fraenkel, J. R., \& Wallen, N. E. (2006). How to design and evaluate research in education. New York: Mcgraw Hill

Holland, J. L. (1997). Making vocational choices: A theory of vocational personalities and work environments (3rd ed.). Odessa, FL: Psychological Assessment Resources.

Johnston, C. S., Luciano, E. C., Maggiori, C., Ruch, W., \& Rossier, J. (2013). Validation of the German version of the Career Adapt-Abilities Scale and its relation to orientations to happiness and work stress. Journal of Vocational Behavior 83 (3): 295304.

Kağıtçıbaşı, Ç. (1996). Özerk-ilişsisel benlik: Yeni bir sentez. Türk Psikoloji Dergisi 11: 36-44.

Kagitcibasi, C., \& Ataca, B. (2005). Value of children and family change: A threedecade portrait from Turkey. Applied Psychology: An International Review 54: 317337.

Kavas, B. A., Duffy, R., Douglass, R. (2015).Exploring links between career adaptability, work volition, and well-being among turkish students. Journal of Vocational Behavior 90, 122-131.

Krumboltz, J.D. (1996). A learning theory of career counseling. In M. L. Savickas \& W. Bruce Walsh (Eds.), Handbook of career counseling theory and practice (pp. 55-80).

Palo Alto, CA: Davies-Black.

McCrae, R. R., \& Costa, P. T., Jr. (2003). Personality in adulthood: A Five-Factor Theory perspective (2nd. ed.). New York: Guilford Press.

Nauta, R., \& Derckx, L. G. M. (2007). Why sin?: A test and an exploration of the social and psychological context of resentment and desire. Pastoral Psychology 56 (2): 177188.

Carr, P.L. (2011). The commitment to securing perpetual journal access: A survey of academic research libraries. Library Resources \& Technical Services 55 (1): 4-16.

Reed, J.A., Ainsworth, B.E., Wilson, D.K., Mixon, G., Cook, A., (2004). Awareness and use of community walking trails. Preventive Medicine 39: 903-908. 
Rossier, J., Zecca, G., Stauffer, S. D., Maggiori, C., \& Dauwalder, J. P.(2012). Career adapt-abilities scale in a french-speaking swiss sample: Psychometric properties and relationships to personality and work engagement. Journal of Vocational Behavior 80 (3), 734-743.

Rottinghaus, P. J., Day, S. X., \& Borgen, F. H. (2005). The career futures inventory: A measure of career-related adaptability and optimism. Journal of Career Assessment 1: $3-24$.

Savickas, M. L. (2012). Life design: A paradigm for career intervention in the $21 \mathrm{st}$ century. Journal of Counseling and Development 90: 13-19.

Savickas, M. L., \& Porfeli, J. E. (2012). Career adapt-abilities scale: Construction, reliability, and measurment equivalence across 13 countries. Journal of Vocational Behavior 80: 661-673

Solberg, E.J. \& Srther, B.E. (1994). Male traits as life-history variables: annual variation in body mass and antler size in moose (Alces alces). Journal of Mammalogy, 68, 10691079.

Srivastava, G. N. \& Bhargava, A. (1984). Personality factors and teaching effectiveness of science pupil-teachers. Journal of Education Research and Extension 21(2): 103-11.

Stumpf, S. A., Colarelli, S. M., \& Hartmann, K. (1983). Development of the career exploration survey (CES). Journal of Vocational Behavior 22: 191-226.

Super, D. E. (1980). A life-span life-space approach to career development. Journal of Vocational Behavior 16: 282-298.

Super, D.E. \& Bohn, M.J. (1970). Occupational psychology. Belmont, CA: Wadsworth Publishing Company, Inc.

Sümer, N., Lajunen, T., \& Özkan, T. (2005). Big Five Personality Traits as the distal predictors of road accident involvement. In G. Underwood, (Eds.), Traffic and transport psychology: Theory and application (pp. 215-227). Oxford: Ellsevier.

Triandis, H.C. 1994. Culture and Social Behavior. New York: McGraw-Hill.

Triandis, H. C. (1996). The psychological measurement of cultural syndromes. American Psychologist 51: 407-415.

Yoon, S. J. (2002) The antecedents and consequences of trust in online purchase decisions. Journal of Interactive Marketing 16 (2): 47-63.

Zacher, H. (2014). İndividual difference predictors of change in career adaptability over time. Journal of Vocational Behavior 84: 188-198.

Zikic, J., \& Klehe, U.C. (2006). Job loss as a blessing in disguise: The role of career exploration and career planning in predicting reemployment quality. Journal of Vocational Behavior 69 :391-409. 


\section{Turkish Abstract \\ Kişilik Özellikleri ve Kariyer Uyumları Açısından Öğretmen ve Öğretmen Adaylarının Karşılaştırılması}

Bu çalışmanın amacı, öğretmenlerin ve öğretmen adaylarının kișilik özellikleri ve kariyer uyumu yönünden karşılaştırmaktır. Bu makalede kişlik özellikleri ve kariyer uyumu arasındaki ilşki de ayrıca incelenmiștir. Çalıșmada 90 erkek ve 76 kadından oluşan toplam 176 öğretmen adayı; 98 erkek ve 106 kadından oluşan toplam 204 öğretmen yeralmıştır. Toplanan veriler Beş Faktörlü Kişilik Envanteri ve Kariyer Uyum Ölçeğinden elde edilen öğeleri içermektedir. Değişkenler arasındaki ilişki cinsiyet farklılığı için bağımsız t-testi ve çoklu yordama analiz teknikleri kullanılarak incelenmiştir. Sonuçlara göre öğretmenlerde kariyer uyum seviyesi öğretmen adaylarından daha yüksek çıkmıştır. Buna ek olarak kariyer incelemesi ve planları belirli kişilik özellikleriyle ilgilidir. Mevcut çalışmanın sonuçları kariyer danışmanlığı ve öğretmenlerin profesyonel gelişimleri için de kullanılabilir.

Anahtar Kelimeler: kariyer uyumu, öğretmen adayları, kişilik özellikleri, kişilik

\section{French Abstract \\ Comparaison de Professeurs et Professeurs de Pré service en ce qui concerne Traits de Personnalité et Adaptabilité de Carrière}

Le but de l'étude est de comparer des professeurs et pré entretenir des professeurs en termes de traits de personnalité et l'adaptabilité de carrière. Les relations entre les traits de personnalité et l'adaptabilité de carrière sont aussi examinées. Un total de 176 professeurs de pré service a participé à l'étude, y compris 90 hommes et 76 femmes et un total de 204 professeurs a participé à l'étude, y compris 98 hommes et 106 femmes. Les données ont rassemblé des articles inclus du Cinq Grand Stock et l'Échelle d'Adaptabilité de Carrière. La relation entre des variables a été examinée en utilisant des t-tests indépendants sur des différences de genre et des techniques d'analyse de régression multiples. Selon les résultats, le niveau d'adaptabilité de carrière est plus haut dans des professeurs que dans des professeurs de pré service. De plus, l'exploration de carrière et des plans ont été liés aux certains traits de personnalité. Les résultats de l'étude présente pourraient être utilisés dans le conseil de carrière et aussi le développement de profession de professeur.

Mots Clés: adaptabilité de carrière, professeurs de pré service, professeurs, traits de personnalité, personnalité 


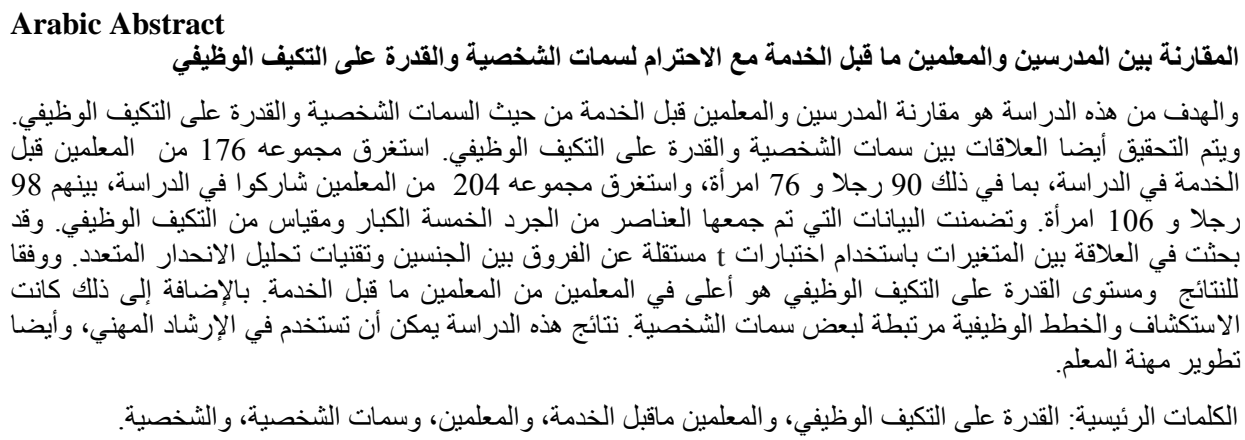

\section{German Abstract}

Vergleich der Lehrer und Pre-Service-Lehrer in Bezug auf Persönlichkeitsmerkmale und Karriere Anpassungsfähigkeit

Das Ziel der Studie ist es, Lehrer und Pre-Service-Lehrer in Bezug auf Persönlichkeitsmerkmale und Karriere Anpassungsfähigkeit zu vergleichen. Die Beziehungen zwischen Persönlichkeitsmerkmalen und Karriereanpassungsfähigkeit werden ebenfalls untersucht. Insgesamt nahmen 176 Pre-Service-Lehrer an der Studie teil, darunter 90 Männer und 76 Frauen und insgesamt 204 Lehrer nahmen an der Studie teil, darunter 98 Männer und 106 Frauen. Die gesammelten Daten umfassten Artikel aus dem Big Five Inventar und das Ausmaß der Karriereanpassungsfähigkeit. Die Beziehung zwischen den Variablen wurde unter Verwendung von unabhängigen $t$-Tests für geschlechtsspezifische Unterschiede und multiple Regressionsanalysetechniken untersuchtNach den Ergebnissen ist das Niveau der beruflichen Anpassungsfähigkeit bei Lehrern höher als bei Lehrkräften. Darüber hinaus wurden KarriereExploration und Pläne im Zusammenhang mit bestimmten Persönlichkeitsmerkmalen. Die Ergebnisse der vorliegenden Studie könnten in der Berufsberatung verwendet werden, und auch Lehrer Beruf Entwicklung.

Schlüsselwörter: karriere anpassungsfähigkeit, pre-service lehrer, lehrer, persönlichkeitsmerkmale, persönlichkeit 


\begin{abstract}
Malaysian Abstract
Perbandingan Guru dan Guru Pra-Perkhidmatan Guru kepada Personaliti dan Penyesuaian Kerjaya

Tujuan kajian ini adalah untuk membandingkan antara guru dan guru pra-perkhidmatan dari segi personaliti dan penyesuaian kerjaya. Hubungan antara personaliti dan penyesuaian kerjaya juga disiasat. Seramai 176 guru pra-perkhidmatan telah mengambil bahagian dalam kajian itu, termasuk 90 lelaki dan 76 wanita, dan sejumlah 204 guru telah mengambil bahagian dalam kajian itu, termasuk 98 lelaki dan 106 wanita. Data yang dikumpul termasuk item dalam Inventori Big Five dan Skala Keupayaan Penyesuaian Kerjaya. Hubungan antara pemboleh ubah telah dikaji dengan menggunakan Ujian-t bebas perbezaan jantina dan pelbagai teknik analisis regresi. Berdasarkan hasil kajian, tahap penyesuaian kerjaya adalah lebih tinggi pada guru berbanding guru pra-perkhidmatan. Selain itu, penerokaan kerjaya dan rancangan adalah berkaitan dengan personaliti tertentu. Keputusan kajian ini boleh digunakan dalam kaunseling kerjaya, dan juga pembangunan profesion guru.
\end{abstract}

Kata Kunci: penyesuaian kerjaya, guru-guru praperkhidmatan, guru, personaliti

\title{
Russian Abstract \\ Сравнение Учителей и Кандидатов в Учителея с Точки Зрения Личностных Качеств и Адаптации к Работе
}

Целью исследования является сравнение учителей и кандидатов учителея с точки зрения личностных черт и адаптивности к работе. В статье исследована отношения между чертами личности и карьеры адаптивности. В общей сложности 176 кандидатов учителя принимали участие в исследовании, в том числе 90 мужчин и 76 женщин, а в общей сложности 204 учителя принимали участие в исследовании, в том числе 98 мужчин и 106 женщин. Собранные данные включали пункты из большой пятерки инвентаризации и масштаба адаптивности к работе. Отношения между переменными былы рассмотрены с исполбзованием независимых т-тестов для гендерных различий и методов множественного регрессионного анализа методики. Согласно результатам, уровень адаптивности к работе выше учителей чем у кандидатов в учителя. Сверх того, исследования карьеры и планов связаны с определенными чертами личности. Результаты данного исследования могут быть использованы в профориентации, а также профессионального развития учителей.

Ключевые Слова: адаптивность к работе, кандидатов в учителя, учителя, личностные черты, личность 